\title{
Az iskolai egészségfejlesztés hazai és nemzetközi szemléletének bemutatása
}

\author{
Introduction of the national and international school health \\ promotion approaches
}

Szerzők: Járomi Éva $\bowtie$, Vitrai József
Nemzeti Egészségfejlesztési Intézet

Beküldve: 2016.02.20.

doi: 10.24365/ef.v58i1.145

\begin{abstract}
„(...) javarészt az iskolának fog jutni az a föladat, hogy a távollevő szülők szerepét betöltse és gondos figyelemmel megelözzön mindent, ami az ifjúság egészségét megkárosithatná, tagjainak épségét megronthatná, vagy éppen életét veszélyeztethetné. Azonkívïl gondoskodni fog alkalmas segítöszerek és eszközök beszerzéséról, melyek az egészség ápolására, a test megedzésére és erejének fönntartására közrehatnak." (Mária Terézia - Ratio Educatio, I777.)
\end{abstract}

Háttér: A magyar lakosság egészsége elmarad az EU fejlettebb tagországaihoz képest. Az egészségveszteségek döntően a viselkedéssel összefüggő kockázatokra vezethetők vissza. A gyermekkorban kialakított egészségmagatartás, kulcsszerepet játszik a lakosság egészségének javításában. A közlemény célja az iskolai egészségfejlesztés egyes megközelítéseinek bemutatása, az esetlegesen fennálló (szemléletbeli) különbségek okainak feltárása. E mellett új fejlesztési lehetőségek bemutatása, majd ezek alapján ajánlások megfogalmazása a szakemberek és döntéshozók számára.

Módszer: Hazai és nemzetközi adatbázisok (MATARKA és PubMed, ScienceDirect, Cochrane Library) alapján szakirodalmi áttekintés készítése. A szakirodalmi keresés a következő kulcsszavakkal történt: iskolai egészségfejlesztés, egészségfejlesztő iskola, iskolai beavatkozások, szervezeti beavatkozás, komplexitás, teljes körűség, rendszer, valamint ezek angol nyelvű megfelelői.

Eredmények: Alapvető szemléletmódbeli különbségek figyelhetők meg az egészségfejlesztésben élenjáró országok és Magyarország között. Míg hazánkban az egészségfejlesztés elszigetelve, az egészségügy peremére szorulva tevékenykedik, addig a kedvezőbb egészségügyi mutatókkal rendelkező államokban (pl. az Egyesült Királyság, Kanada) az egészségfejlesztés egy sokszereplős, interszektoriális rendszerben múködik. Az említett országokban részvételen alapuló, koordinált, komplex adaptív rendszerként tekintenek az egészségfejlesztésre, mely a helyi közösségbe ágyazva, integráltan múködik. Más megközelítések szerint az egészségmagatartás, mint például az elhízást eredményező egészségtelen táplálkozás is kulturálisan befolyásolt, komplex probléma. Feltételezhető, hogy az egészségfejlesztési törekvések, mint pl. az elhízás visszaszorításának sikertelenségét is egyfajta „ördögi kör” magyarázza: egy adott közösség kultúrája egyben akadálya is a kultúra megváltoztatásának.

Következtetések: A hazai iskolai egészségfejlesztés teljes körűségét előíró jogi szabályozások önmagukban nem elegendőek a köznevelési intézmények egészségfejlesztési tevékenységeinek hatékony megvalósításához, pedig az iskolai színtéren történő egészségfejlesztés kitörési pont lehet az egészségkultúra megváltoztatásához. A hatékony egészségfejlesztéshez komplex megközelítésre van szükség, azaz a társadalmi szereplők különböző szinten megvalósuló, összehangolt tevékenységére. A járási szinten jogszabályban előírt közösségi egészségtervezés lehetőséget kínál a komplex iskolai egészségfejlesztés Magyarországon történő megvalósitására.

Kulcsszavak: iskolai egészségfejlesztés, egészségfejlesztő iskola, iskolai beavatkozások, komplexitás, teljes körűség 
Background: The health status of the Hungarian population lags behind the developed EU member states. The losses of health are mainly attributed to the risks associated with behavior. The health behavior developed in childhood plays a key role in the improvement of population health. The aims of the paper are to present different school health promotion approaches and the exploration of causes behind the detectable conceptual differences of them. Furthermore new possible development directions are introduced and recommendations for professionals and policy makers.

Method: Literature review was performed using national and international databases (MATARKA and PubMed, ScienceDirect, Cochrane Library). The literature research was conducted with the following keywords: school health promotion, health-promoting school, school interventions, organizational interventions, complexity, comprehensiveness, system.

Results: Fundamental differences can be observed in the view of health promotion between the cutting edge countries and Hungary. While in our country, the health promotion operates isolated at the margin of health care, meanwhile in the states with more favorable health indicators (e.g. United Kingdom, Canada), the health promotion operates as a multi-stakeholder, inter-sectorial system. In the above mentioned countries the health promotion is regarded as a participative, coordinated, complex adaptive system which is integrated and embedded within the local community. According to other approaches the health behavior like unhealthy diet resulting in obesity is a complex problem and influenced by the culture. It may be assumed that the failures of the health promotion efforts like the obesity reducing are explain with some kind of "vicious cycle": the culture in a given community is its own obstacle to change.

Conclusions: Legal prescribing comprehensiveness for school health promotion alone is not sufficient for the effective implementation of health promotion activities in the public educational institutions in Hungary. However the school health promotion can be the opportunity for breaking the vicious cycle of changing the culture of health. Complex approach is needed for effective health promotion and for coordinated activities of the social actors at different levels. Community health planning prescribed by law at the district level provides opportunities for the implementation of the complex school-health promotion in Hungary.

Keywords: school health promotion, health-promoting school, school interventions, complexity, comprehensiveness

\section{HÁTTÉR}

A magyar lakosság egészsége a legtöbb egészségmutatóban elmarad az EU fejlettebb tagországaihoz képest. Egyes keringési- és rosszindulatú daganatos megbetegedések halálozásában egyre nő a lemaradásunk. Igen jelentős a hátrányunk az egészségügyi ellátással elkerülhető és a népegészségügyi beavatkozásokkal megelőzhető halálozásokban. Az összes elvesztett egészséges életév Magyarországon 22\%kal haladta meg az EU15 országokban megfigyelhető értéket 2015-ben. A hazai egészségveszteségek döntően a viselkedéssel összefüggő kockázatokra vezethetők vissza, ahogyan ezt a magyar egészségmagatartási mutatóknak az EU-ban kirívóan rossz értékei is alátámasztják. Jelentős javulást ezért csakis a lakosság egészségmagatartásának megváltoztatásától lehet várni. ${ }^{1}$

Köztudott, hogy a gyermekkorban kialakított egészségmagatartás kulcsszerepet játszik a lakosság egészségének javításában, ezért a köznevelési intézményekben történő egészségfejlesztési beavatkozások kiemelt szerepet kell, hogy kapjanak a népegészségügyi beavatkozások körében. ${ }^{2}$ Napjainkra számos közlemény született az egészségfejlesztési programok hatékonyságának témájában, melynek eredményei alapján megállapítható hogy az eddigiektől eltérő beavatkozásokra van szükség a hatásos- 
ság érdekében. Az iskolai egészségfejlesztés a többi színtéren történő beavatkozásnál ígéretesebbnek tûnik, melyet jelen közlemény keretében járunk körül. 3, 4, 5, 6

A közlemény célja az iskolai egészségfejlesztés hazai és nemzetközi megközelítéseinek ismertetése, az esetlegesen fennálló szemléletbeli különbségek okainak feltárása, új fejlesztési lehetőségek bemutatása, majd ezek alapján ajánlások megfogalmazása a szakemberek és döntéshozók számára.

\section{MÓDSZER}

A közlemény készítése során a szerzők a hazai és nemzetközi (MATARKA és PubMed, ScienceDirect, Cochrane Library) adatbázisokban végeztek szakirodalmi áttekintést. A kutatás során alkalmazott kulcsszavak: iskolai egészségfejlesztés, egészségfejlesztő iskola, iskolai beavatkozások, szervezeti beavatkozás, komplexitás, teljeskörüség, rendszer, valamint ezek angol megfelelői, úgymint health promoting schools, school interventions, organizational interventions, complexity, completness, system. Mindemellett a releváns szakirodalmak hivatkozásaiban is történt keresés.

\section{EREDMÉNYEK}

Az egészségfejlesztés elméleti alapjai

A nemzetközi gyakorlat áttekintése előtt célszerű megismerni az iskolai egészségfejlesztési beavatkozásokat alakító elméleti alapokat, különböző modelleket. Vizsgálatok sora igazolja, hogy az egészségveszteségek megelőzése érdekében nem elegendő csupán az ismeretek nyújtása. A pozitív irányú változás eléréséhez a fizikai és szellemi készségek fejlesztésén túlmenően a motivációra is hatni kell, valamint az egészséges életmódot támogató megfelelő társas és fizikai környezet kialakítása is szükséges. Ezt a viselkedés megváltoztatását leíró modellt, az ún. COM-B rendszert Michie és munkatársai 2011-ben dolgozták ki, szintetizálva valamennyi akkor ismert viselkedésváltoztatást leíró elméletet. ${ }^{7}$

A modell három alapvető meghatározó tényezőt tartalmaz, úgymint pszichológiai és fizikai képesség (Capability), szociális és fizikai környezet (Opportunity) - amely megfogalmazás tágabb értelmezésben az egyént körülvevő környezetet jelenti-, automatikus és reflektív motiváció (Motivation), amelyek a viselkedést (Behavior) befolyásolják. [1. ábra]

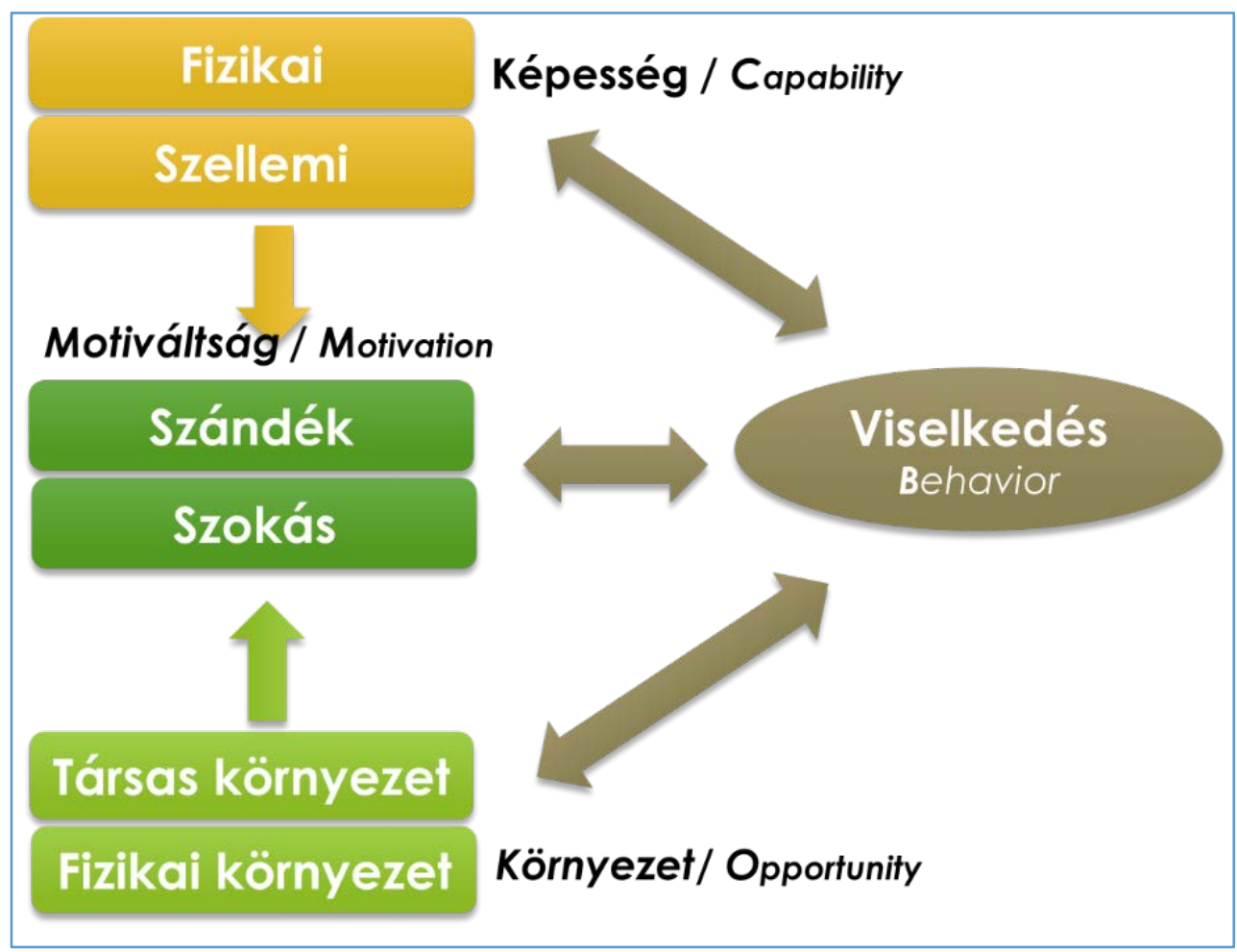

Forrás: Kimmel Zs, Vitrai J (2015) 
A fent említett tényezők képezik a viselkedés megváltoztatásához javasolt ún. „Viselkedésváltoztatás kerekének" középpontját, melyet két körgyűrű vesz körül: 9 féle beavatkozási típus és 7 szakpolitikai eszköz. [2. ábra]
A modell szerint a viselkedés sikeres megváltoztatásához valamennyi befolyásoló tényezőre ható, többféle szakpolitika, többféle beavatkozásának összehangolt megvalósulása szükséges. ${ }^{2}$

2. ábra: $A$ „Viselkedésváltoztatás kereke"

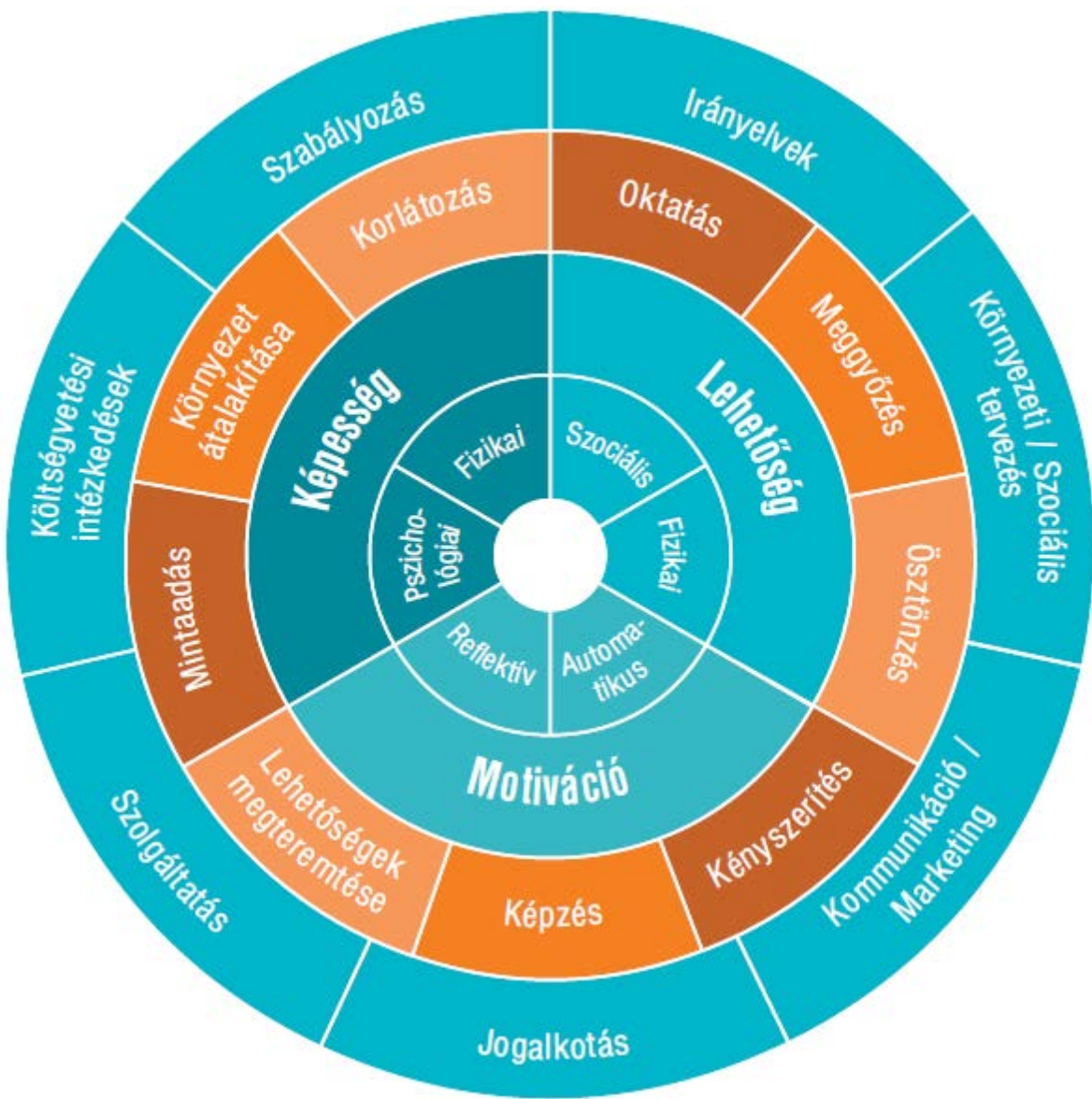

Forrás: Michie S, van Stralen MM, West R (2011)

Egy másik megközelítés szerint az adott egyén viselkedését nagyban befolyásolja az őt körülvevő - a tágan értelmezett kultúrával azonosítható - társadalmi kontextus. ${ }^{9}$ A kultúra jelentésének nincs egységesen elfogadott definíciója. Az egyik leggyakoribb megfogalmazás szerint: azon tanult normák, értékek, hiedelmek és szokások rendszere, amely az adott közösség/társadalom viselkedését befolyásolja. ${ }^{10} \mathrm{Az}$ ennél szélesebben értelmezett jéghegymodell szerint: a jéghegy vízszint feletti részének megfeleltethető az emberek viselkedése és annak eredményei, mint például a nyelv, a kommunikáció, a jogszabályok, a műalkotások, a termékek, a rítusok, stb. Míg a jéghegy víz alá merülő 90 százaléka jelképezi a kultúra nem megfigyelhető, de a viselkedést meghatározó elemeit. Ide tartoznak egyfelől a tudatos értékek, normák, a tudás, a vélemény, az elvárt szerepek, az ideológiák, a hiedelmek és a világnézet. A viselkedést azonban nemcsak a tudat, hanem a tudat alatti tényezők, úgymint előítéletek, gondolati sémák, attitűdök, elvárások, vágyak, feltételezések is befolyásolják. A jéghegy „víz alatti" része szűrőként - egyfajta szemüvegként szolgál az egyénhez vagy közösséghez érkező információk értelmezéséhez, az ön- és világkép kialakulásához. [3. ábra] Mind a tudatos, mind a tudat alatti tényezők a szocializáció során szinte észrevétlen módon rögzülnek, és azzal egészen addig nem szembesülünk, míg egy idegen kultúrával nem találkozunk. ${ }^{11}$ 


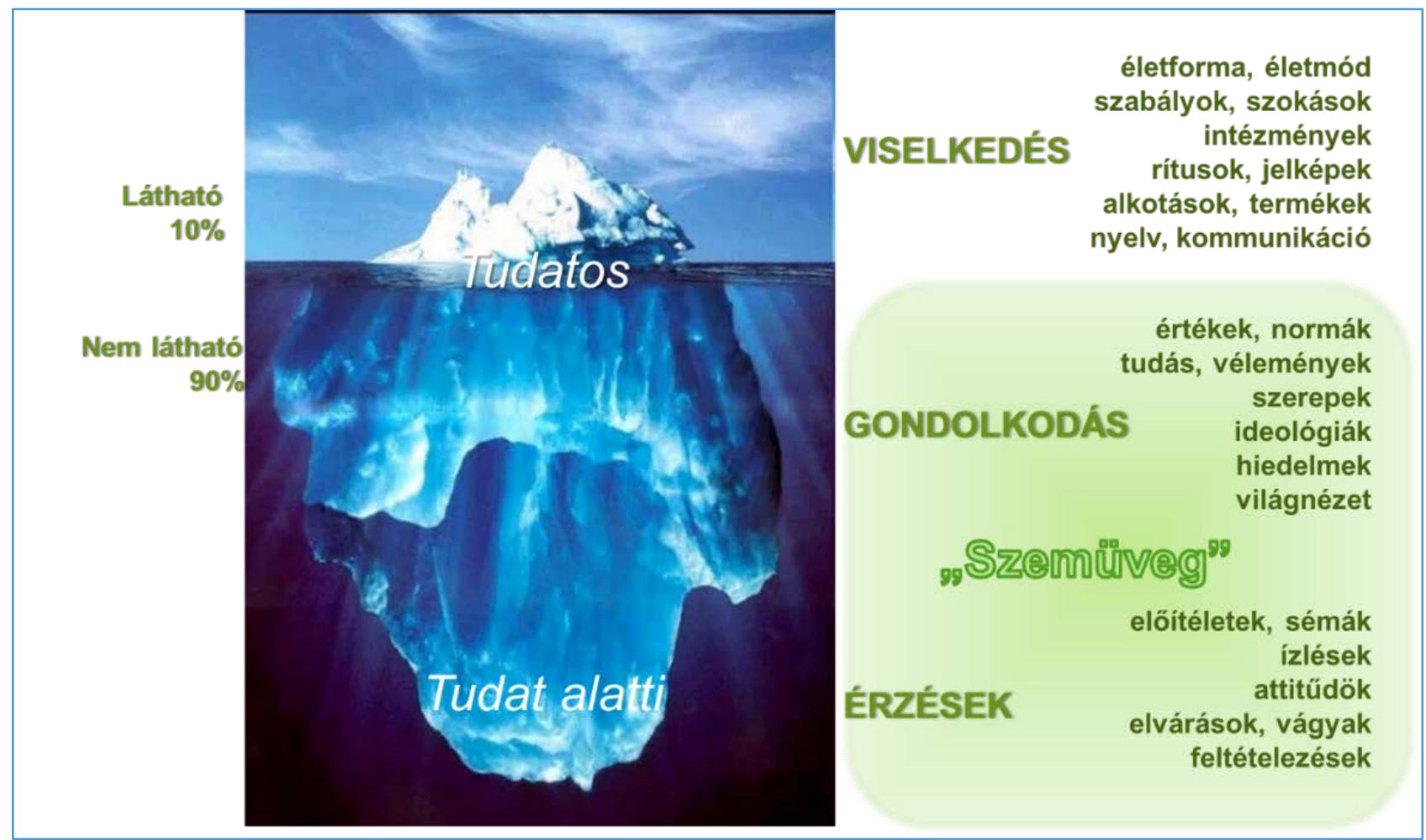

Forrás: Rocher G (1969) ${ }^{12}$

4. ábra: Egészségbarát viselkedést befolyásoló hatásháló

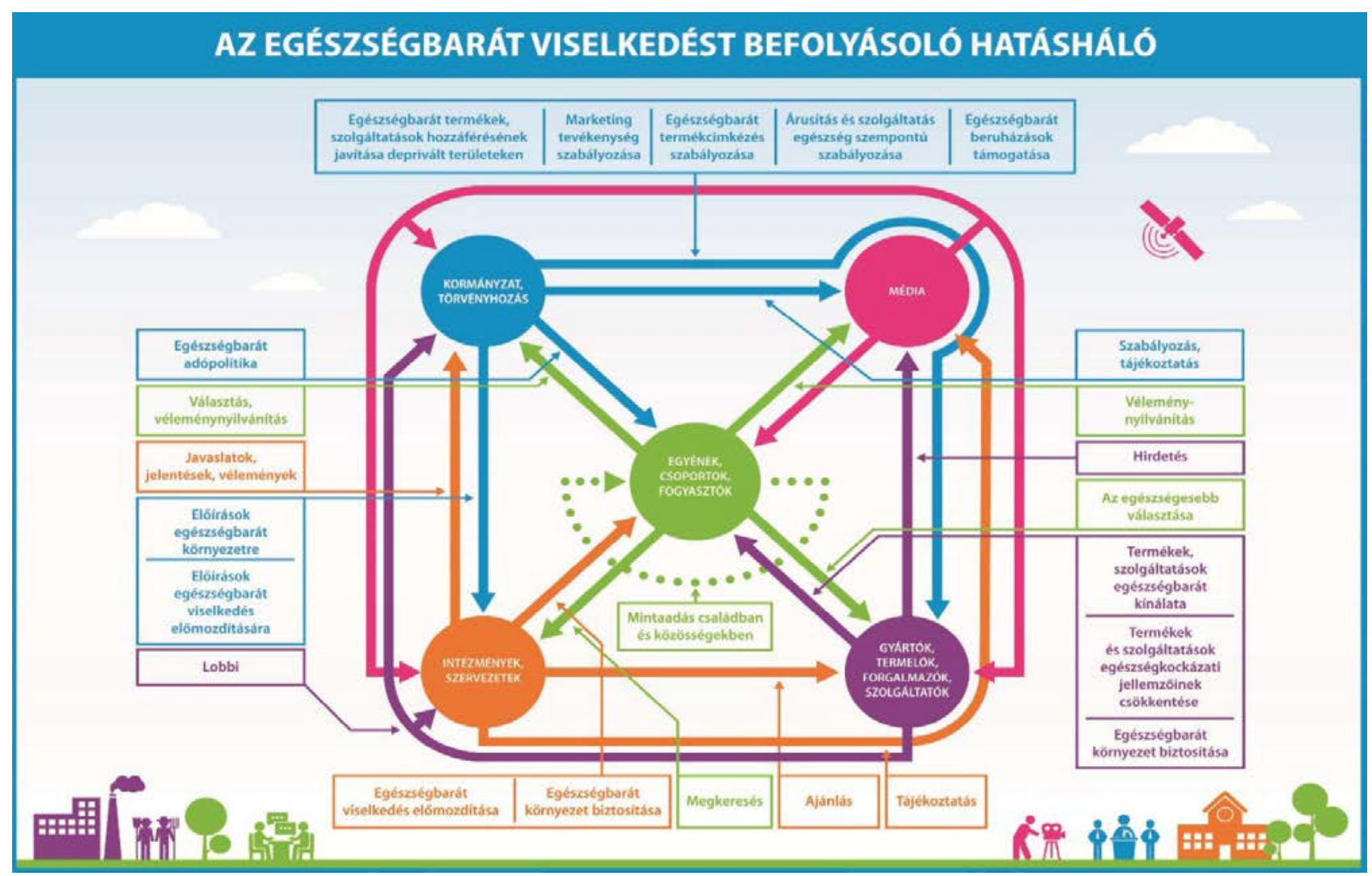

Forrás: Csizmadia P, Varsányi P, Ferenczi M, Vitrai J (2015.) ${ }^{13}$ 
Az újabb rendszertudományi megközelítés szerint a viselkedésváltoztatás eléréséhez többféle intervenciós eszközzel és többféle társadalmi-gazdasági szereplő bevonásával, többféle szakpolitikai irányból szükséges beavatkozni. ${ }^{14}$ Ez egy úgynevezett hatáshálóval szemléltethető, amely az egészséges életmód kormányzati és egyéb társadalmi szereplők általi támogatásának, szerepének lehetőségeit, kapcsolatát szemlélteti, ily módon segítve a rendszer komplexitásának, többszintűségének és non-lineáris tulajdonságának megértését. [4. ábra]

A fenti ábra a hatáshálót ábrázolja, amely az egészségbarát viselkedés kialakulásában szerepet játszó közremúködőket, a közöttük fennálló főbb kapcsolati irányokat és az azokat pozitív irányba befolyásolni képes hatásokat mutatja be. Az egészségbarát viselkedés kialakításában résztvevő társadalmi szereplők részét képezi a kormányzat törvényalkotási része, amelybe nemcsak a központi szereplők, hanem a helyi önkormányzatok is beletartoznak. Az intézmények, szervezetek, úgymint az államigazgatási és nem állami szereplők, egészségügyi, oktatási intézmények, és non-profit civil szervezetek képezik a hatásháló társadalmi szereplőinek egy következő csoportját. A gyártók, termelők, forgalmazók, szolgáltatók körét pedig valamennyi ilyen tevékenységet végző közösség alkotja (pl. az egészségügyi szolgáltatók, élelmiszerüzletek). A negyedik csoport a média, amely valamennyi, kommunikációs tevékenységet végző szereplő összefoglaló megnevezése. Az egyének, csoportok, fogyasztók magukban foglalják például a családot, a lakóközösségeket, a munkahelyi és vallási közösségeket is. ${ }^{13}$

Valamennyi említett társadalmi szereplő magatartása, így a jogszabályalkotás vagy az iskolai menü összeállítása, az egészséggel kapcsolatos médiatartalmak közreadása kulturálisan befolyásolt, komplex probléma. Feltételezhető, hogy az egészségfejlesztési törekvések - mint például az elhízás visszaszorítás - sikertelenségét is egyfajta "ördögi kör" magyarázza: egy adott közösség kultúrája egyben akadálya is a kultúra megváltoztatásának. A változás kulcsszereplőinek, mint például az egészségfejlesztési szakembereknek, pedagógusoknak a viselkedését ugyanis - a COM-B modellnek megfelelően - éppen a megváltoztatni kívánt kultúra által meghatározott szemléletmód, motiváció és környezet akadályozza.
Az iskolai egészségfejlesztés legújabb elméleti megközelítései

Az egészségmagatartás megváltoztatását célzó egészségfejlesztés fő irányát - lehetséges kitörési pontját - az iskolai egészségfejlesztés jelenti több szempontból is. Az iskolában az egészségfejlesztés célcsoportja koncentráltan elérhető. Emellett a gyermekek idejük egy jelentős részét az iskolában töltik, távol a családi - esetlegesen negatív mintát közvetítő - környezettől. Ebben az életkorban a személyiségfejlődés még nem zárult le, a fiatalok még fogékonyak a változásra, az új gondolkodási sémák elsajátítására. További előny, hogy a gyerekek egészségmagatartásának megváltoztatásához csak egy viszonylag szűk, felsőfokú képzettséggel rendelkező csoport (egészségfejlesztési szakemberek, pedagógusok) egészségkultúráját, és ezen keresztül viselkedését szükséges megváltoztatni. Mindemellett fontos megjegyezni, hogy az iskolán kívüli társadalmi szereplők számára a gyermekek egészségének megóvása a saját egészségük fejlesztésénél is nagyobb motivációt jelent.

Mclsaac és munkatársai az iskolai egészségfejlesztést a hatásháló elgondoláshoz hasonló megközelítéssel a társadalmi szereplők és rendszerek közötti többszintú kapcsolatot vizsgálták. ${ }^{15}$ Szerintük az iskolai egészségfejlesztést egy olyan komplex rendszerként kell elképzelni, amelyben az iskolák maguk is összetett rendszerként múködnek. A tanulók alkotta osztályközösségek, a tanári kar, a szülők ennek a rendszernek a szereplői. Viselkedésüket eltérő érdekek és szövevényes viszonyrendszerek alakítják. Az iskola ugyanakkor a helyi társadalom rendszerébe ágyazva, jó néhány társadalmi-gazdasági szereplővel (pl. önkormányzat, közétkeztető, civil szervezetek, stb.) együttmúködik. Az iskolák ezen felül részei az országos szintû köznevelési intézményrendszernek is, amely jogi szabályozással, források biztosításával és szakemberképzéssel befolyásolja az iskolák múködését, infrastruktúráját.

A rendszertudomány szerint a rendszereket négy csoportra osztják a komplexitásuk mértéke szerint: egyszerú, komplikált, komplex (ezen belül adaptív és non-adaptív) valamint ún. káosz rendszerek. Egy komplex adaptív rendszer lehet mesterséges (pl. számítógépes modell), természetes ( $\mathrm{pl}$. immunrendszer) és társas (pl. egyénekből és szervezetekből felépülő helyi társadalom. Az iskola egy társas 
komplex-adaptív rendszer, melynek fő jellemzői: a beágyazottság, az adaptáció formájában történő folyamatos változás, a sokszínúség és a hálózatos múködésmód. ${ }^{16}$

Egy másik megközelítés szerint, amelyik az iskolát szintén komplex színtérként értelmezi, a hatásos iskolai egészségfejlesztésnek három alapvető követelménynek kell megfelelnie: részvétel, koordináció és integráció. ${ }^{17} \mathrm{~A}$ három feltételt további öt ismérv egészít ki: személyesség, partnerek közötti szinergiák, kapcsolatépítés, horizontális és vertikális kommunikáció, valamint az egészség szempontjának a döntéshozásba történő integrálása. A szerzők hangsúlyozzák, hogy a részvétel nemcsak az iskolák szintjén értelmezendő, hanem a szervezeti struktúrában felettük elhelyezkedő tankerületek, önkormányzatok, egyéb felügyeleti és döntéshozói szervek szintjén is. Az egészségfejlesztési beavatkozások megvalósításában ugyanis nemcsak a szúk iskolai közösség vesz rész, hanem a tankerületek is, akik irányelvekkel támogatják az egyes intézkedések beágyazását a rendszerbe és a folyamatokba.

A komplex megközelítésmód a WHO gyermekkori elhízással kapcsolatos jelentésében is megjelenik, miszerint ez a kórkép a meglehetősen összetett egészségproblémák közé sorolandó. ${ }^{18}$ Az elhízás számos szereplőt (egyént, csoportot, szervezetet, stb.) érint, akik között a fennálló kapcsolatok kiemelkedő jelentőséggel bírnak a beavatkozások eredményességének szempontjából. Ezért a WHO „többdimenziós kihívásként” értelmezi az elhízás visszaszorításának feladatát. Annak érdekében, hogy a túlzott testtömeg-növekedést komplex problémaként sikeresen tudjuk kezelni, a korábbiaktól egészen eltérő, innovatív módszerek és megoldások szükségesek - állapítja meg a jelentés.

Az egészségfejlesztési beavatkozások nemritkán az egészségegyenlőtlenségek növekedésével járnak együtt, aminek oka feltehetően a komplex rendszerek - egyelőre előre nem látható - viselkedése. A szerző a rendszertudományi kutatások eredményeire támaszkodva igazolja, hogy a komplex rendszerek viselkedésének mélyebb megértése nélkül nem lehet hatékony és egyenlőtlenségeket kiegyenlítő egészségfejlesztési beavatkozásokat megvalósítani. ${ }^{19}$
Az iskolai egészségfejlesztés nemzetközi megközelítései

Az iskolai egészségfejlesztés jelentőségét már 1987ben felismerte az USA Betegségmegelőzési és Járványügyi Központja (Centers for Disease Control and Prevention, továbbiakban: $C D C$ ), és már abban az időben is egyfajta koordinált, többszereplős egészségfejlesztésről beszélt. Létrehozta a Koordinált Iskolai Egészség Programot (Coordinated School Health Program, továbbiakban: (SH), amely magában foglalja az oktatás, az egészség és a szociális ágazat erőforrásait is.

Az amerikai példához hasonló kezdeményezés Európában 1991-ben jött létre Egészségfejlesztő Iskolák Európai Hálózata (European Network of Health Promoting Schools, ENHPS) keretében, három nemzetközi szervezet, az Európai Bizottság, az Európa Tanács és a WHO Európai Regionális Irodája közös kezdeményezéseként. Kezdetben hét, mára több mint negyven ország képviselői vesznek részt benne. Napjainkra a hálózat önálló szervezeti struktúrában működik, Iskolák az Egészségért Európában (Schools for Health in Europe, továbbiakban: SHE Network) néven. ${ }^{2}$ A SHE Network 6 célterületet fogalmaz meg. [1. táblázat] Állásfoglalása szerint az iskolai egészségfejlesztés alappillérei az iskolai egészségfejlesztés teljeskörűsége, sokszereplős mivolta, törekvése a magasabb minőségű oktatásra és iskolai eredményekre, tudományos bizonyítékokra épülő beavatkozásai, valamint az iskolák aktív közösségi szerepvállalása, közösségfejlesztése, amely által hozzájárulnak a helyi társadalmi tőke fejlesztéséhez és a közösség egészségmúveltségének növeléséhez. ${ }^{20}$

A WHO által 1995-ben kifejlesztett újabb irányelvében megegyeztek abban, hogy az Egészségfejlesztő Iskolák (Health Promoting Schools, HPS) képesek áthidalni az egészség és a tanulás között fennálló szakadékot. A kezdeményezés fő célja, hogy a leghatékonyabban támogathassa az egyes államok iskolai egészségfejlesztési kezdeményezéseit. ${ }^{21} \mathrm{~A}$ korszerü iskolai egészségfejlesztés a világ legtöbb országában a WHO által deklarált alapelveken nyugszik és az általa javasolt intervenciós logikát alkalmazza. Ezen megközelítés használatával az iskolai közösségek a szakpolitika fejlesztésén, a támogató társas és fizikai 
környezet, az iskolai közösségi kapcsolatok, a személyes egészséggel kapcsolatos készségek és hatékony egészségügyi szolgáltatások kialakításán munkálkodnak. A megközelítés 30 éve létezik, azóta pedig e témában jó néhány tanulmány vizsgálta és értékelte a hatásosságra vonatkozó kérdéseket. Számos bizonyíték áll rendelkezésre, amely szerint a HPS megközelítés az egészség számos fontos területét képes fejleszteni, azonban a hatásosságát az eddigi vizsgálatok nem tudták igazolni. ${ }^{22}$

A WHO 2013-ban kidolgozott stratégiájával összhangban a CDC továbbfejlesztette a CSH programját, és meghirdette a Teljes Iskola, Teljes Közösség, Teljes Gyermek koncepciót (Whole School, Whole Community, Whole Child; WSCC). ${ }^{23}$ Az új modell összefogja és továbbgondolja a hagyományosan koordinált iskolai egészség megközelítést és a „Teljes gyermek" (Whole Child) modell elemeit. [1. táblázat] A koncepció alapján az iskolák olyan átfogó és komplex programokat valósíthatnak meg, illetve szolgáltatásokat hozhatnak létre, melyek elősegítik az egészség fejlesztését és a krónikus betegségek valamint azok kockázatának megelőzését. Míg a koordinált iskolai egészségfejlesztés-szemlélet nyolc komponensből áll, ez a modell már tíz összetevőt tartalmaz. ${ }^{2}$

Az elmúlt évtizedben számos közlemény (több mint 131 cikk) vizsgálta a komplex rendszerek különböző megközelítéséit, illetve azok alkalmazhatóságát, mely arra enged követeztetni, hogy a rendszerszinten történő gondolkodás, a rendszerszemlélet nemzetközi viszonylatban már hosszú évek óta a szakemberek közbeszédének részét képezi a népegészségügyben. ${ }^{24}$

\section{A jelenlegi magyar iskolai egészségfejlesztés meg- közelítései}

A több mint ezer éve fennálló magyar iskolarendszer történetének szinte minden időszakában jelen voltak egészségvédelmi törekvések. Már Mária Terézia Ratio Educatio c. 1777-ben kiadott rendeletében is megfigyelhető ez a szándék. ${ }^{25} \mathrm{Az}$ évtizedek során aztán számos nemzeti program fókuszba helyezte az egészségfejlesztést, amelynek történeti át- tekintését a 2015-ben megalkotott Teljes körű Iskolai Egészségfejlesztési Koncepció (továbbiakban TIE Koncepció)' részletesen tárgyalja. ${ }^{2} \mathrm{E}$ cikkben a hangsúlyt a hazai egészségfejlesztés jelenlegi szemléletének és helyzetének áttekintésére helyeztük.

Meleg és munkatársai szerint a tanulók egészségmagatartásának formálásához vezető megfelelő út egy mentálhigiénére alapozott szervezetfejlesztés modell, amelynek lényege, hogy bevonja az iskolai élet minden szereplójét, a tanulók és a pedagógusok mellett az orvosokat, védőnőket, pszichológusokat illetve a szülőket is. ${ }^{26}$ Egy másik megközelítés az egészségfejlesztés témakörét az egyén időgazdálkodásának szempontjából, élete „megélésének” szubjektív, személyes oldaláról vizsgálja. Az emberek azon törekvéséhez, szükségletéhez kapcsolódik, hogy a rendelkezésükre álló időt (és a teret is) lehetőségeikhez mérten számukra a legmegfelelőbb tartalommal töltsék ki. Ennek megvalósításában (pl. megfelelő mennyiségû fizikai aktivitás, megfelelő időintervallumban történő táplálkozás, közösségi idő, stb.) az iskola értékközvetítő szerepe meghatározó lehet. ${ }^{27}$

Egy 2004-ben végzett kutatás, mely a közoktatásban történő egészségfejlesztés mértékének és tartalmának feltérképezését célozta, már felhívta a figyelmet a holisztikus egészségfelfogás (az egészség testi-lelki-szociális tényezők feltétele) hiányára. ${ }^{28}$ Problémaként értékelte, hogy az iskolák sok esetben a prevenció kevésbé aktív résztvevői. Ismeretközlési tevékenységükbe inkább külső szakembereket vonnak be, annak ellenére, hogy a pedagógusok készségfejlesztésére nagyobb szükség lenne. A kutatás további tanulsága, hogy az iskolák vezetői és pedagógusai nincsenek tudatában a mintaadás, az iskolai légkör és az egészségnevelési tartalmak tananyagokba integrálásának hasznával, amely a tanulók életmódját a jelenben, életminőségét pedig a jövőben pozitív irányba mozdíthatja. ${ }^{29} \mathrm{E}$ célból már az 1990-es évek elejétől a pályakezdő és a gyakorló pedagógusok számára egyaránt szerveznek egészségfejlesztési témájú továbbképzéseket és egészségtan tanári kurzusokat. ${ }^{30}$ Azonban ezek a képzések nem hoztak számottevő pozitív irányú változást az iskolai egészségfejlesztésben.

\footnotetext{
A dokumentum a TÁMOP -6.1.2.A-14/1-2014-0001 - Teljes körű Iskolai Egészségfejlesztés projekt (továbbiakban TIE projekt) keretében, a teljes körú iskolai egészségfejlesztésre vonatkozó rendelkezések (a 20/2012. (VIII. 31.) EMMI rendelet), valamint az „Egészséges Magyarország 2014-2020” Egészségügyi Ágazati Stratégiához kapcsolódva került megalkotásra.
} 
Az utóbbi 10 évben született jogszabályok, szakmai programok és anyagok további támogató közeget kínálnak az iskolai egészségfejlesztés számára." A 2003. évi LXI. törvény például az iskolák egészségfejlesztési és egészségnevelési feladatainak jogi szabályozását tartalmazza, melynek célja, hogy a pedagógiai programokban megvalósuljanak az egészségfejlesztési elemek. A 20/2012. (VIII. 31.) EMMI rendeletben már megjelent az iskolai egészségfejlesztés kapcsán a teljes körűség fogalma. A jogalkotó célja az volt, hogy minden gyermek részesüljön a teljes testi-lelki jóllétét, egészségét, egészségi állapotát hatékonyan fejlesztő, a nevelési-oktatási intézmény mindennapjaiban rendszerszerűen működő egészségfejlesztő tevékenységekben. Ezen kívül az iskolai egészségfejlesztési munka színvonalának növelése céljából rendelkezett arról is, hogy oktatási intézményekben csak olyan programok jelenhetnek meg, melyek rendelkeznek a Nemzeti Egészségfejlesztési Intézet (NEFI) szakmai ajánlásával. Deutsch 2011-ben végzett kvalitatív kutatása azt mutatja, hogy bár az iskolai egészségnevelési pedagógiai programok elkészültek, a holisztikus egészségfelfogás helyett az esetek többségében főként az egészség fizikai aspektusára helyezik a hangsúlyt, elhanyagolva annak szociális és lelki dimenzióit. ${ }^{31} \mathrm{~A}$ TIE Kutatás 2015-ben végzett iskolai egészségkultúra felmérésének eredményei szerint, a jogi szabályozás ellenére a mintában szereplő intézmények csupán 69\%-a rendelkezik évenként felülvizsgált egészségfejlesztési programmal. ${ }^{32} \mathrm{~A}$ korábban említett 2004-ben végzett felmérés pedig megállapította, hogy azokban az iskolákban volt eredményes a vizsgált egészségnevelési program, ahol az gondos helyzetelemzésre épült, és figyelembe vette a tanulók, a szülők javaslatait, továbbá kiértékelték a végrehajtás eredményességét is. ${ }^{28}$ Azonban az előírt rendelkezések, programok megvalósulását nagymértékben befolyásolja, hogy a fenntartó és az intézmény vezetője, valamint a pedagógusok menynyire elkötelezettek a témában, e mellett milyen mértékben állnak rendelkezésre anyagi és emberi erőforrások. ${ }^{2}$
A Magyar Diáksport Szövetség 2013-ban útnak indította az Testnevelés az Egészségfejlesztésben Stratégiai Intézkedések (T.E.S.I.) elnevezésű kiemelt projektjét, melynek fókuszába az egészségfejlesztés egyetlen eleme, a fizikai aktivitás került. iii,33 A projekt egyik kutatás-fejlesztési feladata az volt, hogy létrehozza a magyar iskolarendszerben egységesen működtethető, egészségközpontú fittség mérési, értékelési rendszerét. Az új fizikai fittség mérési rendszerben a Nemzeti Egységes Tanulói Fittségi Teszt (NETFIT) segítségével mérik fel a testnevelők a diákok fittségi állapotát az adott tanév meghatározott mérési időszakában. ${ }^{34}$

Egy másik egészségmagatartáshoz - egészséges étkezés - kapcsolódóan több előremutató szabályozási lépés történt. A táplálkozás-egészségügyi előírásokról szóló 37/2014 EMMI rendelettel, iv illetve az iskolai büfék árukínálatát korlátozó 20/2012 EMMI rendelettel ${ }^{v}$ a jogalkotók célja az iskoláskorúak egészséges táplálkozási szokásainak elősegítése volt. ${ }^{35}$

Ezen intézkedések mellett megjelentek az Európai Unió által finanszírozott, a lakosságra, a fiatalokra és kiemelten az iskolai egészségfejlesztésére fókuszáló programok is (TÁMOP 3.1-es és 6.1-es azonosító jelű konstrukciók és pályázatok). Az oktatási ágazat döntéshozói (ismét) felismerték az iskola kiemelkedő szerepét az egészségfejlesztésben, melyet a már említett a 20/2012 EMMI rendelet megalkotásával, valamint a TIE projekt megvalósításával kívántak elősegíteni. ${ }^{2}$ Az elsősorban gyermekeket és pedagógusokat célzó projekt ugyan jelentős számban elérte a célcsoportokat és számukra hasznos egészségismeretet nyújtott, a komplex beavatkozások hiánya (az iskolát körülvevő környezet és a többi társadalmi szereplő bevonásának, és a motivációnak az elmaradása) miatt tartós pozitív irányú változást elérni nem volt képes. A projekt fenntartási kötelezettségének keretében létrejött az Iskola-Egészség Központ, melynek kiemelt feladata az iskolai egészfejlesztési programok szakmai színvonalának, hatásosságának és megbízhatóságának emelése. ${ }^{36}$

\footnotetext{
ii Például a Nemzeti Alaptanterv kiadásáról, bevezetéséről és alkalmazásáról szóló 110/2012. (VI.4.) Korm. rendelet továbbiakban: 110/2012. (VI.4.) Korm. Rendelet; a NAT és a kerettantervek kiadásának és jóváhagyásának rendjéről szóló 51/2012. (XII. 21.) számú EMMI rendelet.

iii „A testnevelés új stratégiájának és a fizikai állapot új mérési rendszerének kialakítása és az önkéntes részvétel ösztönzése a komplex iskolai testmozgásprogramok szervezésében"

iv 37/2014. (IV. 30.) EMMI rendelet „tilos egyebek mellett a szénsavas vagy cukrozott üdítő, valamint a magas zsírtartalmú húskészítmények felhasználása. A közétkeztetésben nem tehetnek az asztalra só- és cukortartót, és előírták, hogy fokozatosan csökkenteni kell a napi bevitt só mennyiségét.”

`20/2012. (VIII. 31.) EMMI rendelet a nevelési-oktatási intézmények működéséről és a köznevelési intézmények névhasználatáról
} 
Az egészséget támogató jogszabályi környezet ellenére, azok megvalósítási feltételeinek biztosítása többnyire elmarad. Emiatt szinte ellehetetlenül a rendelkezésekben foglaltaknak való maradéktalan megfelelés, alátámasztva a komplex stratégiák és beavatkozások hiányát, illetve azok hatását. A 2011. évi CXC. nemzeti köznevelésről szóló törvényben előírt mindennapos testnevelés megfelelő minőségben történő megszervezését például számos iskola, pusztán infrastrukturális korlátok miatt, nem képes megvalósítani. A mindennapos testnevelést az intézmények többségében a tornatermi férőhely hiánya akadályozza például, melyet nem külső sportlétesítmények használatával, hanem sok esetben szükségmegoldásokkal, például osztálytermi órákkal (20\%), vagy egyéb, nem testnevelési célra kialakított, belső helyiségek használatával hidalnak át az egyes intézmények. ${ }^{32}$

1. táblázat: Az iskolai egészségfejlesztés jelentősebb megközelitéseinek áttekintő táblázata

\begin{tabular}{|c|c|c|c|}
\hline $\begin{array}{c}\text { SHE } \\
\text { (Európa, 2011) }\end{array}$ & $\begin{array}{l}\text { TIE } 4 \text { alaptevékenység (Ma- } \\
\text { gyarország, 2012) }\end{array}$ & $\begin{array}{c}\text { WSCC } \\
\text { (USA, 2014) }\end{array}$ & $\begin{array}{c}\text { TIE Koncepció } \\
\text { (Magyarország, 2015) }\end{array}$ \\
\hline $\begin{array}{l}\text { 1. Egyéni egészséggel kap- } \\
\text { csolatos készségek és kom- } \\
\text { petenciák }\end{array}$ & $\begin{array}{l}\text { 1. Az egészségismeretek } \\
\text { készség szintű elsajátításá- } \\
\text { nak elősegítése }\end{array}$ & 1. Egészségnevelés & $\begin{array}{l}\text { 1. Ismeretátadás, készség- } \\
\text { fejlesztés }^{\text {vi }}\end{array}$ \\
\hline \multirow[t]{2}{*}{$\begin{array}{l}\text { 2. Egészséges iskola irány- } \\
\text { elv }\end{array}$} & $\begin{array}{l}\text { 2. Mindennapos testneve- } \\
\text { lés }\end{array}$ & $\begin{array}{l}\text { 2. Testnevelés és fizikai ak- } \\
\text { tivitás }\end{array}$ & $\begin{array}{l}\text { 2. Átfogó fizikai aktivitás } \\
\text { (Életmód, egészségmaga- } \\
\text { tartás célterület kereté- } \\
\text { ben) }\end{array}$ \\
\hline & 3. Egészséges táplálkozás & $\begin{array}{l}\text { 3. Étkezési körülmények és } \\
\text { szolgáltatások }\end{array}$ & $\begin{array}{l}\text { 3. Egészséges táplálkozás } \\
\text { elősegítése (Életmód, } \\
\text { egészségmagatartás célte- } \\
\text { rület keretében) vii }\end{array}$ \\
\hline \multirow[t]{2}{*}{$\begin{array}{l}\text { 3. Egészségügyi szolgáltatá- } \\
\text { sok }\end{array}$} & $\begin{array}{l}\text { 4. A gyermekek kiegyensú- } \\
\text { lyozott, érett személyiség- } \\
\text { fejlődésének (azaz lelki } \\
\text { egészségének) elősegítése }\end{array}$ & $\begin{array}{l}\text { 4. Egészségügyi szolgálta- } \\
\text { tások }\end{array}$ & $\begin{array}{l}\text { 4. Egészség szolgáltatások } \\
\text { (az egyes tanulókat támo- } \\
\text { gató szolgáltatások) }\end{array}$ \\
\hline & & $\begin{array}{l}\text { 5. Tanácsadás, lelki és szo- } \\
\text { ciális szolgáltatások }\end{array}$ & $\begin{array}{l}\text { 3. Egyéni mentorálási } \\
\text { funkció }\end{array}$ \\
\hline 4. Iskolai társas környezet & & 6. Társas és érzelmi légkör & $\begin{array}{l}\text { 5. Iskolai kultúra, pozitív } \\
\text { légkör }\end{array}$ \\
\hline \multirow[t]{2}{*}{ 5. Fizikai környezet } & & 7. Fizikai környezet & $\begin{array}{l}\text { 6. Megfelelő fizikai környe- } \\
\text { zet }\end{array}$ \\
\hline & & 8. Dolgozók jól-léte & 7. Iskolai dolgozók jól-léte \\
\hline \multirow{3}{*}{ 6. Közösségi kapcsolatok } & & 9. Családok bevonása & $\begin{array}{l}\text { 8. Megfelelő családi kör- } \\
\text { nyezet kialakítása }\end{array}$ \\
\hline & & & 9. Közösségi szerepvállalás \\
\hline & & 10. Közösségek bevonása & $\begin{array}{l}\text { 10. Iskolán kívüli közössé- } \\
\text { gek bevonása }\end{array}$ \\
\hline
\end{tabular}

Forrás: Saját szerkesztés

\footnotetext{
${ }^{v i}$ A WSCC-megközelítés azonos pontjához hasonlóan, ebbe a pontba az ismeretátadáson túl a formális, strukturált egészségnevelés is beleértendő, amely az oktatás-nevelési tervek kombinációját tartalmazza (bővebben Id. TIE Koncepció, 2015. 55. o.).

vii Tartalmazza a diákok számára a megfelelő étkezési időt és az étkezés megfelelő körülményeit, a mosdókon kívül ingyenes vízvételi lehetőséget, továbbá az iskolai büfékben (valamint az étel és ital automatákban) az egészséges étel- és italválasztás lehetőségét, ezzel is hozzájárulva az egészséges életmód kialakításához (bővebben Id. TIE Koncepció, 2015. 56. o.).
} 


\section{KÖVETKEZTETÉSEK}

A bemutatott iskolai egészségfejlesztési megközelítésekről összefoglalóan elmondható, hogy alapvető szemléletmódbeli különbségek és lemaradás figyelhető meg az (iskolai) egészségfejlesztésben élenjáró országok és hazánk között. Nemzetközi szinten a szakpolitikai döntéshozásban is megjelenik a komplex rendszer szintű gondolkodás, az iskolát szintén komplex adaptív rendszer részeként értelmezik, valamint az iskolai egészségfejlesztést egy részvételen alapuló, koordinált, a helyi közösségbe ágyazva, integráltan, számos társadalmi szereplő bevonásával, több beavatkozási irányból megközelítve valósítják meg. Ezzel szemben hazánkban az egészségfejlesztés, az iskolai egészségfejlesztés is elszigetelt területként, az egészségügy peremterületére szorulva, különálló diszciplínaként jelenik meg. A jelenleg uralkodónak tekinthető itthoni szemlélet, az iskolai teljes körű egészségfejlesztés a gyakorlatban mindössze négy alaptevékenységet foglal magában. ${ }^{37}[1$. táblázat] A tevékenységek a problémában érintetteknek csupán egy szűk körét, a pedagógusokat, a gyermekeket és azok szüleit célozzák.

Az alábbi táblázat összefoglalja az egészségfejlesztés hazai és nemzetközi megközelítéseit, illetve annak célterületeit.

Habár Magyarországon számos előremutató iskolai egészségfejlesztést támogató kezdeményezés van, azonban ezek elszigetelt módon valósulnak meg, nélkülözve az egyes beavatkozások valódi rendszerszerű, interszektoriális összefonódását, egymásra épülését. Emellett további problémát jelent, hogy nincs törekvés az igazoltan hatásos, korszerű szemléletű beavatkozások kiválasztására és azok megvalósítására. Ezek helyett továbbra is kampányszerű, lényegében ismeretátadásra fókuszáló programok zajlanak.

Annak érdekében, hogy az egészségfejlesztési beavatkozások hatásosan és eredményesen valósuljanak meg, alapvető szemléletmód váltásra van szükség. Ennek eléréséhez a népegészségügyi szakemberek és a pedagógusok képzésének olyan átalakítására van szükség, ami alkalmas a komplex szemléletmód kialakítására.

Egy 7544 egészségfejlesztést vizsgáló elemzés áttekintés arra enged következtetni, hogy a több elemből álló, komplex szemléletet tükröző iskolai beavatkozások, melyek tartalmazzák, pl. az iskolai irányel- vek fejlesztését, a szülők bevonását, a helyi közösségekkel való együttmúködést, hatékonynak bizonyulnak a szexuális egészség elősegítésében, az iskolai erőszak valamint a dohányzás megelőzésében. Ugyanakkor az említett területeken túl, számos beavatkozás, mint például az alkohol- és a droghasználat csökkentését célzó programok hatékonyságára vonatkozóan kevés a rendelkezésre álló bizonyíték. ${ }^{6}$ Ezért ezen programok kidolgozásakor a rendszerszemléletű, komplex szemléletmód kialakítására kell törekedni.

Egy másik áttekintés szerzői éppen ezért azt ajánlják a CSH és a WSCC megközelítést [1. táblázat] alkalmazó iskolai egészségfejlesztést kutatóknak, hogy „fókuszáljanak a WSCC modell rendszer-tulajdonságára, ezen belül is a közösség szerepére." ${ }^{4}$

Az új szemlélet és korszerű módszertan elsajátításával a szakemberek képesek lesznek kedvező irányba módosítani az egészségkultúrát a gyermekek körében, akik felnőve uralkodóvá teszik azt, ezáltal teremtve esélyt az "ördögi kör” megszakítására a jövőben.

A hazai iskolai egészségfejlesztést előíró jogi szabályozások folyamatos fejlesztése mellett kiemelt fontosságú lenne a megvalósítást biztosító források, valamint módszertani támogatás nyújtása.

A hatékonyan múködő hazai iskolai egészségfejlesztés egy lehetséges irányát képezheti a közösségek szintjén történő beavatkozás, amelyre az 1997. évi CLIV. törvény az egészségügyről 152/B. §-ban szabályozott járási szintű egészségtervezés lehetőséget kínál. ${ }^{38} \mathrm{~A}$ járási egészségtervezés - összhangban a magasabb szintû stratégiai dokumentumokkal - alkalmas lehet az iskola helyi közösségi rendszerbe integrálására, valamint a döntéshozók figyelmének felkeltésére egyaránt. A járási egészségtervezés alapot teremt a helyi kulcsszereplők együttmúködési lehetőségének biztosítására, a korábban bemutatott hatásháló modelljében ábrázoltakhoz hasonlóan. [4. ábra] Emellett mozgósítja az erőforrásokat a helyi közösség, az önkormányzat, a helyi államigazgatási szervek, a civil szervezetek és egyének körében és szinkronizálja tevékenységeiket. $A$ járási egészségtervezés megvalósulása hosszú távon hozzájárulhat a járás lakosságának - ezen belül pedig az iskolás korúk - egészségi állapot javulásához, valamit a fennálló egészségbeli egyenlőtlenségek csökkentéséhez. ${ }^{39} \mathrm{Az}$ egészségtervezési folyamat kulcsszereplői lehetnek a továbbiakban az Egészségfej- 
lesztési Irodák, valamint a Közösségi Egészségtervezési Irodák. ${ }^{40} \mathrm{~A}$ fenti elképzelést támogatja a 2016 ban megrendezett Shanghai konferencia megállapítása is, amelyben kimondják, a helyi szintű kezdeményezések hatásosan működnek, és a közösségek, a városok az egészség különösen fontos helyszínei. ${ }^{41}$

${ }^{1}$ Varsányi P, Vitrai J. (szerk.) Egészségjelentés2016 - Információk a népegészségügyi beavatkozások célterületeinek azonosításához a nem fertőző betegségek és az egészségmagatartási mutatók elemzése alapján, Nemzeti Egészségfejlesztési Intézet, 2017. (Megjelenés alatt)

${ }^{2}$ Teljes Körű Iskolai Egészségfejlesztési Koncepció. Nemzeti Egészségfejlesztési Intézet, 2015. http://projektek.egeszseg.hu/documents/17618/2222750/Teljes+k\%C3\%B6r\%C5\%B1+lskolai+Eg\%C3\%A9szs\%C3\%A9gfejleszt\%C3\%A9s+Koncepci\%C3\%B3.pdf/9bd631f4-b027-4802-8cec-3e343f29c5fe?version=1.0 (Elérve: 2017.01.28.)

3 David V. McQueen; Strengthening the evidence base for health promotion. Health Promot Int 2001; 16 (3): $261-268$ doi: 10.1093/heapro/16.3.261

${ }^{4}$ Rasberry CN, Slade S, Lohrmann DK, Valois RF. Lessons learned from the whole child and coordinated school health approaches. J Sch Health. 2015; 85: 759-765.

${ }^{5}$ Brian R. Flay, D. Phil. Efficacy and effectiveness trials (and other phases of research) in the development of health promotion programs Preventive Medicine Volume 15, Issue 5, September 1986, Pages 451-474.

${ }^{6}$ N. Shackleton et al. School-Based Interventions Going Beyond Health Education to Promote Adolescent Health: Systematic Review of Reviews Journal of Adolescent Health 58 (2016) 382e396 https://www.ncbi.nlm.nih.gov/pubmed/27013271 (Elérve: 2017.03.11.)

${ }^{7}$ Michie S, van Stralen MM, West R. The behaviour change wheel: A new method for characterising and designing behaviour change interventions. Implement Sci. 2011; 6: 42. doi: 10.1186/1748-5908-6-42

${ }^{8}$ Kimmel Zs, Vitrai J. Mennyire változtatható jogszabályokkal az egészségmagatartás? Elegendőek-e a szabályozások az egészségmagatartás megváltoztatásához? II. rész. Egészségtudomány, IIX. Évfolyam, 2015. 3. szám

${ }^{9}$ Davies, SC, Winpenny E, Ball S, Fowler T, Rubin J, Nolte E. (2014) For Debate: A New Wave in Public Health Improvement. The Lancet. doi:10.1016/S0140-6736(13)62341-7.

${ }^{10}$ Hruschka, DJ, Hadley C. 2008. A Glossary of Culture in Epidemiology. Journal of Epidemiology and Community Health 62 (11): 947-951. doi:10.1136/jech.2008.076729.

${ }^{11}$ Járomi É, Szilágyi K, Vitrai J. (2015) Az egészségkultúra fogalma, vizsgálatának lehetőségei a köznevelési intézményekben - Szakirodalmi áttekintés Egészségfejlesztés LVI. évf. 2015. 5-6. szám

${ }^{12}$ Guy Rocher, Introduction à la sociologie générale, Tome 1, 1969.

${ }^{13}$ Csizmadia Péter, Dr. Varsányi Péter, Ferencz Mihály, Vitrai József PhD Az egészségbarát viselkedést befolyásoló hatásháló Egészségfejlesztés, 2014;5-6:10-14

${ }^{14}$ Hawkes, C. et al. Smart food policies for obesity prevention, The Lancet 2015, published online Feb19.

${ }^{15}$ Mclsaac J. D., Hernandez KJ, Kirk SF, Curran JA. (2016) Interventions to Support System-level Implementation of Health Promoting Schools: A Scoping Review. Int J Environ Res Public Health. 2016 Feb 6;13(2):200. doi: 10.3390/ijerph13020200. Review. PubMed PMID: 26861376, PMCID: PMC4772220

${ }^{16}$ Keshavarz N, Nutbeam D, Rowling L, Khavarpour F. Schools as social complex adaptive systems: a new way to understand the challenges of introducing the health promoting schools concept. Soc Sci Med. 2010 May;70(10):1467-74. doi: 10.1016/j.socscimed.2010.01.034. Epub 2010 Feb 12.

${ }^{17}$ Gleddie D. (2012) A journey into school health promotion: district implementation of the health promoting schools approach. Health Promot Int. 2012 Mar;27(1):82-9. doi: 10.1093/heapro/dar053. PubMed PMID: 21903687

${ }^{18}$ Gluckman P, Nishtar S, Armstrong T. Ending childhood obesity: a multidimensional challenge. Lancet. 2015 Mar 21;385(9973):1048-50. doi: 10.1016/S0140-6736(15)60509-8.

${ }^{19}$ Matheson A. Perspectives Reducing social inequalities in obesity: complexity and power relationships Journal of Public Health | Vol. 38, No. 4, pp. 826-829 doi:10.1093/pubmed/fdv197

${ }^{20}$ Better Schools through Health, the Third European Conference on Health Promoting Schools, Vilnius Resolution, 2009. http://ec.europa.eu/health/ph determinants/life style/mental/docs/vilnius resolution.pdf (Elérve: 2017.01.28.)

${ }^{21}$ SHE strategic plan 2013-2016. SHE assembly meeting on 10 October 2013. 
${ }^{22}$ Langford R, et al The WHO Health Promoting School framework for improving the health and well-being of students and their academic achievement. Cochrane Database of Systematic Reviews 2014, Issue 4. Art. No.: CD008958. DOI: 10.1002/14651858.CD008958.pub2.

${ }^{23}$ Whole school, whole community, whole child; ASC D, CDC, 2014. http://www.cdc.gov/healthyyouth/wscc/ (Elérve: 2017.01.28.)

${ }^{24}$ Carey G, Malbon E, Carey N, et al Systems science and systems thinking for public health: a systematic review of the field. BMJOpen 2015; 5:e009002. doi:10.1136/bmjopen-2015-009002

${ }^{25}$ Mária Terézia Ratio Educatio, I. Fejezet. A tanulóifjúság egészségi állapotának gondozása CXXII §. A tanulóifjúság egészségi állapotát illető rendtartási intézkedésről általában (1777).

${ }^{26}$ Meleg Cs: Életminőség: egészségmegőrzés és egészségfejlesztés Új Pedagógiai Szemle, 1997. június http://epa.oszk.hu/00000/00035/00006/1997-06-mh-Meleg-Eletminoseg.html (Elérve: 2017.01.28.)

27 Soósné Faragó M. Az idő és az egészség Új Pedagógiai Szemle, 2005. június http://epa.oszk.hu/00000/00035/00093/2005-06-ta-Soosne-Ido.html (Elérve: 2017.01.28.)

28 Paksi B., Felvinczi K, Schmidt A: Prevenciós, egészségfejlesztési tevékenység a közoktatásban. 2004. http://www.nefmi.gov.hu/2005/prevencios-tevekenyseg (Elérve: 2017.01.28.)

${ }^{29}$ Kaposvári K: Az iskolai egészségnevelési és környezetnevelési programok megvalósulása http://www.ogyei.hu/anyagok/ISKOLAEGESZSEGUGYI FELMERES.pdf (Elérve: 2017.03.11.)

${ }^{30}$ Fodor József Iskolaegészségügyi Társaság weboldala http://www.fjit.hu/bemutatkozas.php (Elérve: 2017.01.28.)

${ }^{31}$ Deutsch K: Iskolai egészségfelfogás és egészségfejlesztés kvalitatív és kvantitatív kutatások tükrében Új pedagógiai szemle - 61. évf. 1-5. sz. (2011.) http://epa.oszk.hu/00000/00035/00145/pdf/EPA00035 upsz 2011 01-05.pdf (Elérve: 2017.03.11.)

${ }^{32}$ Iskolai Egészségkultúra felmérés - kutatási jelentés, GfK (2015.) http://www.egeszseg.hu/szakmai oldalak/oldal/szakmai-anyagok/szakmai-anyagok-iskolai-egeszseges-eletmod-kutatas-es-felmeres/ (Elérve: 2017.02.19.)

${ }_{33}$ Magyar Diáksport Szövetség weboldala - TESI projekt bemutatása http://www.mdsz.hu/tesi/ (Elérve: 2017.03.16.)

${ }^{34}$ Magyar Diáksport Szövetség weboldala - NETFIT áttekintés http://www.mdsz.hu/netfit/netfit-attekintes/ (Elérve: 2017.03.16.)

${ }^{35}$ Ajánlás az iskolai büfék korszerű táplálkozásba illeszkedő választékának kialakításához, OÉTI, 2005.

${ }^{36} \mathrm{NEFI}$ weboldala http://www.egeszseg.hu/szakmai oldalak/oldal/szervezeti-egysegek,egeszsegfejlesztesi-igazgatosag/iskola-egeszseg-kozpont/(Elérve: 2017.02.1.)

37 Somhegyi A. (2012): A teljes körű iskolai egészségfejlesztés országos megvalósítását elősegítő elemek a nemzeti köznevelésről szóló 2011. évi CXC törvényben Népegészségügy/90. évfolyam 3. szám http://www.lefnet.hu/resources/userfiles/K\%C3\%B6znev\%20tv\%20\%C3\%A9s\%20egfej|\%20N\%C3\%A9peg\%C3\%A9szs\%C3\%A9g\%C3\%BCgy\%202012-12-10-09.pdf (Elérve: 2017.03.11.)

38 1997. évi CLIV. törvény az egészségügyről 152/B. § „a járásra, illetve a fővárosban a fővárosi kerületre vonatkozóan” https://net.jogtar.hu/jr/gen/hjegy doc.cgi?docid=99700154.TV (Elérve: 2017.02.19.)

${ }^{39}$ Bezzegh $P$, Vitrai J. Útmutató a járási/kerületi egészségterv elkészítéséhez, NEFI, 2016.

${ }^{40}$ Túri G, Vitrai J. A közösségi egészségtervezés módszertana IME XIV. évf. 3. szám 2015. április http://www.imeonline.hu/article.php?article=2015. XIV./3/a kozossegi egeszsegtervezes modszertana\# (Elérve: 2017.03.11.)

${ }^{41}$ Shanghai Declaration on promoting health in the 2030 Agenda for Sustainable Development, 9th Global Conference on Health Promotion, Shanghai 2016 http://www.who.int/healthpromotion/conferences/9gchp/shanghai-declaration.pdf?ua=1 (Elérve: 2017.02.19.) 